\title{
Demystifying Phraseology: Implications for Translating Quranic Phraseological Units
}

\author{
Hassan Badr Hassan*, Karim Menacere \\ Liverpool Business School, John Moores University, Brownlow Hill, Liverpool L3 5UG, UK \\ Corresponding Author: Hassan Badr Hassan, E-mail: H.B.Hassan@2014.1jmu.ac.uk
}

\section{ARTICLE INFO}

Article history

Received: September 12, 2018

Accepted: November 20, 2018

Published: February 28, 2019

Volume: 10 Issue: 1

Advance access: January 2019

Conflicts of interest: None

Funding: None

Key words:

Quran,

Phraseology,

Multiword Expression,

Exegesis,

Translation,

Faithfulness,

Accuracy

\begin{abstract}
This paper examines phraseology as a lexical feature from a Quranic perspective. It explores the importance of demystifying the phraseological theoretical base in order to facilitate the task of translators and second language learners and deal more efficiently with the challenging language aspects of phraseology. Despite prolific publications and the growing interest that research on phraseology generates, too many grey areas still prevail, and many questions remain unanswered. There is a degree of inconsistency and stalemate in the phraseology debate, often yielding fragmented literature and inconclusive evidence. Research on phraseology remains stuck at the level of description and prescription. Similarly, research on translation studies seldom moves beyond comparative analysis of language pairs, examining cross linguistic and cultural differences. The literature does not have a strong theoretical base and is largely anecdotal, lacking empirical data from which to draw clear-cut conclusions on the key issues of translating phraseology. This paper focuses on five selected English translations of the Quran to assess the degree of faithfulness and accuracy in rendering the Quranic phraseology into English. Findings suggested the five selected translators of the Quran fell short of checking exegesis of the Quranic text. The findings revealed that translations of the Quranic phraseological units gave an echo at best. Results showed the literal translation method was frequently used for translating phraseology; however, this often led to inaccurate and stilted English. The findings suggest that the translation of the Quran in English is still a work in progress, and it needs to be periodically evaluated and updated to address the flaws identified by researchers from different perspectives. Findings are polarised between those who advocate as close a rendering of the Quranic text as possible and those who believe in a 'natural style' in the target text. This study is pertinent because it has several practical implications. Firstly, it will benefit translators of the Quran by providing fresh insights on how to deal with some of the challenges of translating Quranic phraseology. Secondly, it will provide a platform for further research on translating Quranic phraseological units and addressing the current shortcomings. This study has also expanded the extant literature on translating Quranic collocations to benefit future researchers.
\end{abstract}

\section{INTRODUCTION}

This paper aims to investigate phraseology as a lexical feature from a Quranic perspective. It explores the importance of demystifying the phraseological theoretical base in order to facilitate the task of translators to deal more efficiently with the challenging language aspects of phraseology. Despite the ongoing research and interest that translation and phraseology generate, there is no real consensus and a degree of inconsistency regarding the way phraseology and translation are defined and explained, making conclusive empirical evidence difficult to find. too many grey areas still prevail, and many questions remain unanswered. There is a degree of inconsistency and stalemate in the phraseology debate, often yielding fragmented literature and inconclusive evidence.
The way language users conceptualise and perceive reality through various linguistic manifestations and mechanisms has long generated interest from both linguists and educationalists. Phraseology can be said to be one of those pervasive language functions that speakers make use of to express a specific communicative purpose. These are used either spontaneously or intentionally to make conversations 'interesting.' It is what makes people actually engage in and enjoy conversations (Nerlich, and Clarke 2001). Different tags have been attached to refer to this word association: recurrent word-combination, word association, recurrent multi-word sequence, set expression, set phrase, idiomatic phrase, multi-word expression, multiword utterance, phraseological unit, formulaic language, phraseme, idiomatic 
expression, idiom, collocation, and/or poly-lexical expression, etc. What adds to the tangle is that these labels are used by authors in differing and often random and interchangeable ways.

Research on phraseology is sometimes conflicting, sometimes complementary, and at times overlapping, saying what has already been said time and time again (Cowie 1991, Howarth 1998; Kjellmer 1994, Sinclair 1991, Stubbs 2001, etc.). As a result, the phraseology debate appears at times blurred and its terminology entwined, partly because of the nature of the topic itself and partly because of an insufficient knowledge base regarding phraseological units. This can be corroborated by the fact that different authors have come to similar findings and conclusions. For instance, Kunin (1970:210) refers to phraseological units as 'semi-idioms' and 'a stable combination of words with a fully or partially figurative meaning.' Phraseology units are often described as constrained multiword expressions with emotive nuance through metaphoric or idiomatic meaning. According to Mel'čuk (1995:7) 'A phraseological expression, or phraseme, is thus a multiword utterance featuring some unpredictable properties, i.e. a constrained utterance, or a multiword utterance that is not free.' Similarly, Moon (1997:43) views multiword units as 'sequences of words which semantically or syntactically form a meaningful or inseparable unit...that can be lexical units or idiom like phrases.' Take for instance, ghost writer, basket case, rogue state, miscarriage of justice, etc.

In the same vein, Gledhill (2011:1) defines phraseology as involving: 'the study of formulaic sequences of words, including idiomatic phrases and proverbial expressions, which stand in contrast to other more prosaic constructions in the language in that they have a highly conventionalised form and frame of reference. 'It seems therefore, that some phraseology units carry a special meaning, often consisting of figurative shades of meaning communicating an emotive language function. As argued by Naciscione (2001:53), the cognitive and communicative purpose of phraseology units is achieved because language users make use of both the literal and the figurative meaning. 'A phraseological unit may extend across sentence boundaries and even large stretches of text, creating a continuity, a web of unique interrelationships of figurative and direct meanings, and associative links.' There are some word combinations and phraseological units which have an emotive value, often used to convey a particular communicative function, for example: 'The icing on the cake." The particular phraseological form by which meaning can be expressed differs from language to language. For instance, in French the imagery changes to La cerise sur le gâteau' (for cherry on the cake), while Pied noir literally means 'black foot' but actually refers to former French settlers in Algeria.

Some word combinations or phraseology units may be viewed as functioning as semantically inseparable word associations operating as single entities, as free combinations or as ready-made units. (Moon 1997, Kunin 1970, Sinclair 1991 and Stubbs 2001). Consider for instance the following examples: green light, green fingers, flesh and blood, blue blood, bog standard, low life, back seat driver, break a leg, keyboard warrior, etc. These phraseological units are a form of loaded language whose main function is to persuade, express emotions or arouse feelings. Phraseological units consist of a denotative meaning which refers to the primary or literal meaning of the word combination as well as a connotative meaning which belongs to the whole word combination, such as 'red tape, tiger mother.' In other words, phraseological units refer to word combinations carrying both a primary meaning and a secondary meaning or a literal and a figurative meaning, where the figurative meaning is predominant. Moreover, phraseological units are context specific i.e. they are used in specific contexts and are non-variable, or fixed sets: small fry, dress to kill, bread and butter.

Phraseology is not an unexplored topic, but scholars are still undecided about what criteria to use that determine when a particular word combination can be classified as a phraseological unit. Although the phraseology debate has been investigated from a wide range of perspectives, key issues remain: the lack of strong theoretical base, sporadic literature on phraseology, vagueness and diversity of definitions and interpretations of phraseology and inadequate criteria for demarcating the boundary and measurement of phraseological units.

\section{THE MUDDLE THAT IS PHRASEOLOGICAL UNITS}

Research on phraseology has provided interesting insights and useful knowledge benefitting both linguists and language learners, yet it is still one of the most challenging language features. The muddle starts with determining why a certain set of words enjoy each other's company and bond well together while others clash. What is the boundary between collocation as a free word combination and a fixed set of phraseological units with a figurative shade of meaning? Although Sinclair (1991), one of the leading authorities on word combinations, indicates that there are two levels which can be used to determine and interpret the meaning of a language text, namely, the Open Choice Principle and the Idiom Principle, there is a fine line between the two options as they are neither uniform nor standardised. As a result, the phraseological units debate is still open, and different labels will continue to be used randomly and interchangeably: set expression, idiom, set phrase, word association, fixed word-groups, multiword expressions (MWEs) and multiword (MW) patterns, readymade phrases, phraseological units etc. They function as a vehicle to convey all possible nuances of meaning without a chance of reaching a consensus regarding a universal term for these word combinations. Thus, the boundary between collocations and phraseological units with a hint of figurativeness is not clear cut; it is more of a hybrid mix. However, this terminological vagueness is just a reflection of language in a real communicative setting and attaching a particular label is of little importance because what is in a name? A phraseological unit by any other name is just a word combination. Most phraseo- 
logical units overlap because communication takes place in interactive and varied ways. As Steyer (2015:7) points out: 'Multiword expressions (MWEs) and multiword (MW) patterns are not clear-cut and distinct entities. On the contrary, fragments and overlapping elements with fuzzy borders are typical for real language use. This means that there really are no MWEs as such. In real communicative situations, some components are focused while others fade into the background."

In short, phraseological units may consist of a range of figurative hints aimed at achieving special effects. Consider for instance the following examples cheap and nasty or cheap and cheerful, fish and chips, airing cupboard. In the case of 'airing cupboard', it would not make sense when translated in Arabic because it is difficult to conceptualise or have a mental image of what the phrase relates to.

\section{PHRASEOLOGICAL UNITS IN THE QURAN}

Arabic is the language of the Quran. Delisle and Woodworth (1995:17) point out there are 'several koranic verses [that] explicitly state that Arabic, and no other language was intended to be the vehicle of the divine word.' According to Pickthall (1935:vii), the Quran is an 'inimitable symphony, the very sounds of which move men to tears and ecstasy." The rhythmic and melodic verses of the Quran have been acknowledged by many scholars. Most of the Quranic text is formulaic language and is self-contained by nature consisting of subtle use of style and diction and the Quran is characterised by frequent repetitions of structures or the same phrases, to the extent that it may be considered, as Arberry (2008:1) put it, 'neither prose nor poetry, but a unique fusion of both.' Some word combinations such as al-hayat (Life) is repeated 145 times, as is الموت almawt (Death).

According to Bannister's study (2014: 230) An Oral-Formulaic Study of the Quran, the Quran is imbued with phraseological units, and it also displays many of the features of oral composition: 'the Quran is steeped in formulaic diction.' Thus, much of the language of the Quran consists of short discrete units which need to be understood as formula or phraseological units and not as individual words. This unique rhythmic style of the Quran makes it easier to memorise, which has been the main source of its preservation.

\section{POSITIONING QURANIC PHRASEOLOGY WITHIN THE BROAD WORD COMBINATION DEBATE}

This section attempts to link the general theoretical base of collocation to that of the Quran in order to find out where Quranic collocations fit within the broad collocation debate. It also seeks to demonstrate whether Quranic collocations are in line with the widely accepted set of criteria for determining collocations. Although research on phraseological units is pervasively acknowledged as an established area in almost all language fields (e.g. Cowie 1994, Baker 1992, Granger \& Meunier 2008, Meunier \& Granger 2008, Römer \& Schulze 2009), there is a paucity of collocational and phraseological studies in Arabic/English. The following examines whether Quranic collocational and/or phraseological units are consistent with the following collocation norms:

1. Strings of words that seem to have a certain mutual expectancy

2. Frequent co-occurrence of two or more words

3. An expression consisting of two or more words with a sense of figurativeness

4. An idiom like lexical unit

5. Arbitrary language items recurrent in context whose meaning cannot be inferred from individual words

6. Word association, word partnership with a hint of figurativeness not intended to be understood literally

The above list is informed from the literature and is by no means set in stone.

It can be argued in light of the above criteria, that Quranic phraseology is considered as one of the most influential and inspiring sources in Modern Standard Arabic as it possesses a large stock. Although Arabic and English have different thought processes and operate from different mind-sets, they may share some features in how phraseological units are used in terms of function and key components. In the case of the Quran, phraseological units fit well within the broad phraseology criteria. The following is a small sample of the vast number of formulaic expressions used in the Quran:

The above formulaic units show regularity and consistency combining with the collocate القول Al-qawli. This word association which is regularly used under the same metrical rhythm is deeply woven into the fabric of the Quran and aims to express a specific communicative purpose. The density and pervasiveness of rhymed prose and phraseological

\begin{tabular}{|c|c|c|c|}
\hline Collocate/ قول & Sura & Translation & Transliteration \\
\hline يثبت الله الذين آمنو ا بالقول الثابت & Ibrahim, $14: 27$ & $\begin{array}{l}\text { God will give firmness to } \\
\text { those who believe in the firmly } \\
\text { rooted word }\end{array}$ & $\begin{array}{l}\text { Yuthabbitu Allāhu Al-Ladhīna 'Āmanū } \\
\text { Bil-Qawli Ath-Thābiti }\end{array}$ \\
\hline فلا تقل لهما أف ولا تتهر هما وقل لهما قو لا & Al-Isra, 17:23 & $\begin{array}{l}\text { Be not harsh with them but } \\
\text { speak to them respectfully }\end{array}$ & $\begin{array}{l}\text { Falā Taqul Lahumā 'Uffin Wa Lā } \\
\text { Tanharhumā Wa Qul Lahumā Qawlāan } \\
\text { Karīmāan }\end{array}$ \\
\hline فقو لا له قو لا لينا & Taha, 20:44 & Speak to him gently & Faqūlā Lahu Qawlāan Layyināan \\
\hline إنا سنلقي عليك قو لا ثقيلا & Al-Muzzammil,73:5 & $\begin{array}{l}\text { We shall send a momentous } \\
\text { message down to you }\end{array}$ & $\begin{array}{l}\text { 'Innā Sanulqī `Alayka Qawlāan } \\
\text { Thaqīlāan }\end{array}$ \\
\hline إنه لقول فصل & At-taariq, $86: 13$ & $\begin{array}{l}\text { This is truly a deceive } \\
\text { statement }\end{array}$ & 'Innahu Laqawlun Faşlun \\
\hline
\end{tabular}


units in the Quran create, in many verses, a mesmerising effect which is inimitable in any other form of literary work. What transpires from the above sample is that Quranic phraseological features are consistent with the broad theoretical base on word combinations with a hint of figurativeness, but they are also unique in the sense that they are used in a divine and creative way to convey a particular purpose. They are formulated in a distinctive way and their meaning is distributed and emphasised often rendering them untranslatable in English.

Some Quranic phraseological units are transparent and explicit. They have become part of everyday language; many people who use them are unaware of their Quranic origin. Consider for instance the following examples:

Bannister's (2014) study suggests that 'Medinan' Quranic verses generally have higher formulaic densities, making more consistent use of formulaic diction as demonstrated in the above phrases or word combinations. They possess a figurative meaning which cannot be deduced from the individual components or literal meaning of the constituent parts. It is this blend of divine character and linguistic specificity that gives the Quranic language its central untranslatable essence. Phraseology in the Quran is a linguistic force and thought-provoking word combinations to express or describe specific situations. Collocations or phraseology units serve a specific communicative function. Phraseological units are an integral part of the language of the Quran and must be interpreted in the context in which they occur; they cannot be translated in isolation. Consider the following phraseological units:

Many parts of the Quran are characterised by the use of:

a) formulaic and emotive language such as phraseology units which enrich Modern Standard Arabic which adopted them

b) phraseology units express a range of emotions and evoke feelings

c) the components of Quranic phraseology units are used in such a creative and sophisticated way that the meaning they carry or emphasise may well be untranslatable in another language. Consider the following examples which demonstrate the use of figurative meaning:

\begin{tabular}{|c|c|c|c|}
\hline $\begin{array}{l}\text { Phraseological } \\
\text { collocations }\end{array}$ & Sura & Translation & Transliteration \\
\hline و عسى أن تكر هو ا شيئا وهو & Al-baqara,2:216 & $\begin{array}{l}\text { You may dislike something although } \\
\text { it is good for you }\end{array}$ & $\begin{array}{l}\text { Wa `Asá 'An Takrahū Shay'āan Wa Huwa } \\
\text { Khayrun Lakum }\end{array}$ \\
\hline ضعف الطالب و المطلوب & Al-Hajj,22:73 & $\begin{array}{l}\text { How feeble are the petitioners and } \\
\text { how feeble are those they petition! }\end{array}$ & Đa ufa Aț-Ţālibu Wa Al-Maţlūbu \\
\hline أعمالهم كرماد اشتدت به الريح & Ibrahim, $14: 18$ & $\begin{array}{l}\text { The deeds of those who reject their } \\
\text { Lord are like ashes that the wind } \\
\text { blows furiously on a stormy day }\end{array}$ & $\begin{array}{l}\text { ‘A`māluhum Karamādin Ashtaddat Bihi } \\
\text { Ar-Rīhu Fī Yawmin `Āşifin }\end{array}$ \\
\hline إن بعض الظن إثم & Al-Hujuraat,49:12 & Some assumptions are sinful & 'Inna Ba`đa Až-Žanni ‘Ithmun \\
\hline فينفع الناس الزبد فيذهب في فاء وأما ما & Ar-Ra'd,13:17 & $\begin{array}{l}\text { The froth disappears, but what is of } \\
\text { benefit to man stays behind }\end{array}$ & $\begin{array}{l}\text { Fa'ammā Az-Zabadu Fayadh/habu } \\
\text { Jufā'an Wa 'Ammā Mā Yanfa`u An-Nāsa } \\
\text { Fayamkuthu Fī Al-'Arđi }\end{array}$ \\
\hline 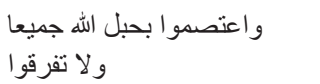 & Al-Imran,3:103 & $\begin{array}{l}\text { Hold fast to God's rope all together, } \\
\text { do not split into factions }\end{array}$ & $\begin{array}{l}\text { Wa A`taşimū Biĥabli Allāhi Jamī̄āan Wa } \\
\text { Lā Tafarraqū }\end{array}$ \\
\hline
\end{tabular}

\begin{tabular}{|c|c|c|c|}
\hline $\begin{array}{l}\text { Phraseological } \\
\text { collocations }\end{array}$ & Sura & Translation & Transliteration \\
\hline بعلم خائنة الأعين وما تخفي & Ghafir,40:19 & $\begin{array}{l}\text { God is aware of the most furtive of } \\
\text { glances, and of all that hearts conceal }\end{array}$ & $\begin{array}{l}\text { Ya’lamu Khā’inata Al-’A 'yuni Wa Mā } \\
\text { Tukhfĩ Aş-Şudūru }\end{array}$ \\
\hline أيحب أحدكم أن يأكل لحم أخيه & Al-Hujuraat,49:12 & $\begin{array}{l}\text { Would any of you like to eat the flesh } \\
\text { of your dead brother? }\end{array}$ & $\begin{array}{l}\text { 'Ayuĥibbu 'Aĥadukum 'An Ya'kula Laĥma } \\
\text { 'Akhīhi Maytāan }\end{array}$ \\
\hline و اشتعل الر أس شيبا & Maryam,19:4 & And my hair is ashen grey. & $\begin{array}{l}\text { Qāla Rabbi ‘Innī Wahana Al-'Ažmu Minnī } \\
\text { Wa Ashta'ala Ar-Ra'su Shaybāan }\end{array}$ \\
\hline
\end{tabular}

\begin{tabular}{|c|c|c|c|}
\hline $\begin{array}{l}\text { Phraseological } \\
\text { collocations }\end{array}$ & Sura & Translation & Transliteration \\
\hline ضعف الطالب و المطلوب & Al-Hajj,22:73 & $\begin{array}{l}\text { How feeble are the petitioners and how } \\
\text { feeble are those they petition! }\end{array}$ & Đa`ufa Aț-Țālibu Wa Al-Maţlūbu \\
\hline حتى يلج الجمل في سم الخياط & Al-A'raaf,7:40 & $\begin{array}{l}\text { Even if a thick rope were to pass through the } \\
\text { eye of a needle. }\end{array}$ & $\begin{array}{l}\text { Ĥattá Yalija Al-Jamalu Fī Sammi } \\
\text { Al-Khiyāţi }\end{array}$ \\
\hline 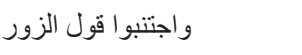 & Al-Hajj,22:30 & Shun false utterances. & Wa Ajtanibū Qawla Az-Zūri \\
\hline و لا تصعر خدك للناس & Luqman,31:18 & Do not turn your nose up at people & Wa Lā Tuşa “ir Khaddaka Lilnnāsi \\
\hline
\end{tabular}


d) Phraseology units extend the use of language to include figures of speech, imagery, metaphor etc.

Today's reality and world view is constantly changing, and language is used in a creative and innovative way to match and keep pace with these changes. Thus, language goes through a process of recreating, readjusting, adapting and accommodating the new jargon so that it fits with current norms and usage, e.g. noughties, multi-tasker, solution-provider, web-master, chip and pin; but the language of the Quran is immutable and timeless. Its message is regarded by Muslims as eternal and universal, transcending time and place, providing guidance on every aspect of human life. In terms of translation, conclusions about what the components of the phraseological units mean by themselves should not be jumped at, but what these word combinations are saying needs to be carefully considered. The spirit, not the form, of the word should be conveyed. Language by its nature is inherently ambiguous, making the expression or understanding of the written or spoken word difficult at times, and grasping the true meaning of the Quran is no exception.

For the purpose of this study, five translations were selected to evaluate the accuracy of rendering phraseological units:

Which English version of the Quran is better or more accurate than another is a matter of debate. Each has its strengths and weaknesses. The five selected translations represent some of the most referred to English translations of the Quran. The rationale for selecting them is summed up as follows:

- Arberry's (2008) translation is the first English translation by a scholar of Arabic. Arberry managed to preserve the faithfulness of the original text by keeping close to the Arabic text. Western scholars consider Arberry's translation as one of the most respected translations achieved by a non-Muslim translator.

- Ali's (2000) translation is one of the most widely used translations in English-speaking countries. It is one of the most popular translations among Muslims and non-Muslims as it is one of the earliest translations of the Quran.

- Abdel Haleem's (2004) translation is a comparatively recent work. Abdel Haleem is a professor of Islamic Studies at the University of London. One of the advantages of Abdel Haleem's translation is that it does not use archaic language and the writing style is user-friendly for readers.

- Asad's (1980) version of the Quran has a parallel Arabic text, useful notes, and four appendices. However, Asad used many footnotes in brackets explanatory words, which, though useful, could have been used more

\begin{tabular}{|c|c|c|c|}
\hline $\begin{array}{l}\text { Phraseological } \\
\text { collocations }\end{array}$ & Sura & Translation & Transliteration \\
\hline وبئر معطلة وقصر مشيد & Al-Hajj,22:45 & $\begin{array}{l}\text { How many deserted wells; how many lofty } \\
\text { palaces }\end{array}$ & $\begin{array}{l}\text { Wa Bi'rin Mu’ațţalatin Wa Qaşrin } \\
\text { Mashīdin }\end{array}$ \\
\hline كل نفس ذائقة الموت & Aal-Imran,3:185 & Every soul will taste death & Kullu Nafsin Dhā̀iqatu Al-Mawti \\
\hline صر عى كأنهم أعجاز نخل خاوية & Al-Haaqqa,69:7 & $\begin{array}{l}\text { So that you could have seen its people lying } \\
\text { dead like hollow palm-trunks }\end{array}$ & $\begin{array}{l}\text { Şar’á Ka'annahum ‘A’jāzu Nakhlin } \\
\text { Khāwiyahin }\end{array}$ \\
\hline
\end{tabular}

\begin{tabular}{|c|c|c|c|}
\hline $\begin{array}{l}\text { Phraseological } \\
\text { collocations }\end{array}$ & Sura & Translation & Transliteration \\
\hline وقل ربي ارحمهما كما ريباني الذن صغيرا الرحمة & Al-Israa, 17:24 & $\begin{array}{l}\text { And lower your wing in humility towards } \\
\text { them in kindness and say, 'Lord, have mercy } \\
\text { on them, just as they cared for me when I } \\
\text { was little }\end{array}$ & $\begin{array}{l}\text { Wa Akhfiđ Lahumā Janāha Adh- } \\
\text { Dhulli Mina Ar-Raĥmati Wa } \\
\text { Qul Rrabbi Arĥamhumā Kamā } \\
\text { Rabbayānī Şaghīrāan }\end{array}$ \\
\hline 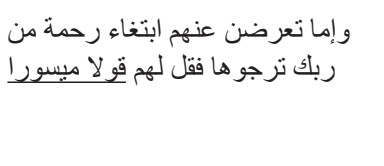 & Al-Israa, 17:28 & $\begin{array}{l}\text { But if, while seeking some bounty that you } \\
\text { expect from your Lord, you turn them down, } \\
\text { then at least speak some word of comfort to } \\
\text { them }\end{array}$ & $\begin{array}{l}\text { Wa ‘Immā Tu`riđanna `Anhumu } \\
\text { Abtighāıa Raĥmatin Min Rabbika } \\
\text { Tarjūhā Faqul Lahum Qawlāan } \\
\text { Maysūrāan }\end{array}$ \\
\hline و لا تجعل يدك مغلولة إلى عنقلك و لا & Al-Israa, 17:29 & $\begin{array}{l}\text { Do not be tight-fisted, nor so open-handed } \\
\text { that you end up blamed and overwhelmed } \\
\text { with regret }\end{array}$ & $\begin{array}{l}\text { Wa Lā Taj`al Yadaka Maghlūlatan } \\
\text { 'Ilá 'Unuqika Wa Lā Tabsuţhā Kulla } \\
\text { Al-Basţi Fataq`uda Malūmāan } \\
\text { Maĥsūrāan }\end{array}$ \\
\hline
\end{tabular}

\begin{tabular}{llcl}
\hline Translators & Titles & Date of edition & Publishers \\
\hline Arberry & The Koran & 2008 & Oxford University Press \\
Ali & The Holy Quran & 2000 & Wordsworth Editions Limited \\
Abdel Haleem & The Quran & 2004 & Oxford University Press \\
Asad- & The Message of the Quran, Translated and Explained & 1980 & Andalus Press \\
Al-Hilali and Khan & Interpretation of the Meaning of the Noble Quran & 1983 & Maktaba Dar-us-Salam \\
\hline
\end{tabular}


sparingly. Asad's approach triggered some criticism from some Muslim theologians. According to Khaleel (2005: 48), 'Asad sought to depart from the traditional exegetic approaches and reflected independent thought.

- Al-Hilali and Khan's (1983) translation, is the most widely published translation as Saudi Arabia has reprinted and distributed millions of copies of this translation worldwide. Moreover, many Muslim scholars favour this translation because it avoids the use of archaisms and was undertaken by two experts.

\section{TRANSLATING QURANIC PHRASEOLOGY}

Understanding how the language of the Quran is communicatively used and how its collocations and rhyming patterns are structurally distributed to convey a particular message, is a prerequisite to translating. One of the salient attributes of the Quran is that it is a closed corpus in the sense that since its revelation and inception, it has not been subject to modification, expansion or change. For Muslims, its authority, authenticity and transparency are undisputed. لا جدال في النص (the authenticity of the Quranic text is beyond dispute). As clearly emphasised in the Quran, 'This is the Scripture in which there is no doubt, containing guidance for those who are mindful of God, who believe in the unseen...' (Al-Baqara, 2:2-3)

ذلك الكتاب لا ريب فيه هدى للمتقين الأين يؤمنون بالغيب ويقيمون

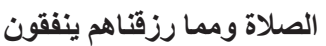

Dhālika Al-Kitābu Lā Rayba Fīhi Hudáan Lilmuttaqīna Al-Ladhīna Yu 'uminūna Bil-Ghaybi Wa Yuqūmūna Aş-Şalāata Wa Mimmā Razaqnāhum Yunfiqūna

Translating Quranic phraseology presents difficulties beyond those encountered in dealing with phraseology in other languages owing to the style and complex structure of the Quran. The translation of Quranic phraseology into English is under-researched and limited to a few miscellaneous articles, proposing a number of different approaches to its translation (Bani-Younes 2015, Jabak et al 2016). All the translation theories, models and strategies provided by literature are useful and offer insights into the translation process. However, there is a knowledge gap in terms of the applicability of the existing theoretical base as most theories, models and strategies are difficult to apply to Arabic/English translation because of differences in the thought processes and mindsets and obviously the linguistic differences. The literature review indicates that a number of studies which have been conducted on Arabic collocations and phraseology lack substance and empirical data to support their findings.

In short, the Quranic text has a high density of phraseology, rhythmic patterns and challenging syntactic structures. The Quran is said to have unique features in terms of eloquence and style, which distinguish it from any other literary Arabic text. Some word combinations of the Quran aim to create several contextual meanings within the same verses. The Quran encompasses a whole range of recurrent word combinations and many of the words form part of a frequent and habitual word-combination in one way or another. Some authors (Dweik \& Abu Shakra 2011, Abdel Haleem 2009) argue that the Quran contains excessive collocational expressions in order to be persuasive, informative and to make an impact. The way phraseology binds together with other language elements, and how the different parts of the Quran are interconnected and explain each other, makes any translation tentative. Every Quranic phraseology has 'a cohesive force' and involves a unique encounter with language and a process of conveying a specific communicative purpose.

\section{A SAMPLE OF QURANIC PHRASEOLOGICAL UNITS IN TRANSLATION}

The process of translating Quranic phraseology involves a unique encounter with language which is said to be both inimitable and untranslatable. Pickthall (1935: vii) stresses that the English translation of the Quran 'is not the Glorious Quran, that inimitable symphony, the very sounds of which move men to tears and ecstasy. It is only an attempt to present the meaning of the Quran - and peradventure something of the charm in English. It can never take the place of the Quran in Arabic, nor is it meant to do so.' The process of translating is not a robotic operation of cloning the SL text but an attempt at understanding, interpreting and conveying the closest natural meaning in TL. The process of interpreting the meaning using different sources in order to unravel the expressive and meaningful nature of the intended message is a prerequisite. Translating is exchanging of information and interacting between the SL and TL texts. The aim is to explain and make the meaning accessible. Quranic phraseological units are characterised by

a) the existence of extended meaning

b) conveying what the message means as opposed to what the words mean

c) understanding is whole phrasal unit-oriented information processing, not a word matching between language items.

d) need to be understood in their actual context of occurrence.

Quranic collocations, phraseology units, are an amalgam of complex, covert, figurative, associative and factual language which can be challenging to understand let alone translate. They come in different forms, types and definitions depending on the focus, the communicative purpose and the author. This study holds the view that the task of translating the Quran is too overwhelming and important to be undertaken by one individual; a collective and team effort and resources can help in achieving a quality translation with confidence. Two views regarding the current translations of the Quran emerged from assessing the quality of the translations of collocations and phraseology units: a) there is an assumption that translating the scripture of such magnitude can be achieved successfully by one individual $b$ ) the other view is that translating the Quran is much more complex. There is no master plan and there are no fast-track solutions to address the challenges except through joining forces to form a task force involving a range of experts. Translating the Quran involves a unique encounter with abstract and complex language features conveying specific communicative purpose and its translation is not so much about producing sameness between SL and TL, but it is about conveying the gist of what was said in SL as efficiently and as closely as possible.

The following demonstrates how phraseological Quranic units have been dealt with in translation. 
Many current translations of the Quran lack consistency, while others are short on quality in terms of fluency and readability. Some of the translators use archaic language which makes it difficult for the reader to understand, e.g. And swell not thy cheek (for pride) at men, while others use a literal translation which often leads to the loss of the nuances of meaning of language from SL to TL as can be seen from this example: ولا تصعر خدك للناس

Although the gist of what was said in the Quran comes across in the above renderings, the lexical choice and expression leave much to be desired (Do not turn your nose up at people And turn not your face away from men with pride). The translators' task is to convey the meaning with clarity and simplicity. To be accessible to all, the Quranic text in translation should be made as simple as possible. For instance, the above could be expressed as do not show contempt for people. In addition, Turn not thy cheek away from men in scorn, And swell not thy cheek (for pride) at men are not gender free which could have been avoided as the original word wiنd does not specifically refer to specifically to men

With regards to the verse واخفض لهما جناح الأل من الرحمة, the five translators struggled with carrying across the figurative meaning جناح الذا preferring to stay close to SL yielding some stilted expression. A better option, would have been to take the meaning across rather than the phraseology such as: treating them with humility and kindness

In the verse قال رب إني وهن العظم مني واشتعل الرأس شيب the translators encountered phraseology which they rendered literally. و واثتعل الر أس شيبي resulting in rather strange phraseology such as my head doth glisten with grey, head is all aflame with hoariness, my hair is ashen grey. Khan and Hilali used a common-sense interpretation suggesting and grey hair has spread on my head. As is the case of most phraseological units, a

\begin{tabular}{|c|c|c|c|c|c|c|}
\hline $\begin{array}{l}\text { Phraseological } \\
\text { collocation }\end{array}$ & Sura & Ali & Arberry & Asad & $\begin{array}{l}\text { Abdel- } \\
\text { Haleem }\end{array}$ & Khan\&Hilali \\
\hline ولا تصعر خدك للناس & Luqman,31:18 & $\begin{array}{l}\text { And swell not } \\
\text { thy cheek (for } \\
\text { pride) at men }\end{array}$ & $\begin{array}{l}\text { Turn not thy } \\
\text { cheek away from } \\
\underline{\text { men in scorn }}\end{array}$ & $\begin{array}{l}\begin{array}{l}\text { And turn not thy } \\
\text { cheek away from }\end{array} \\
\text { people in [false] } \\
\text { pride }\end{array}$ & $\begin{array}{l}\text { Do not turn } \\
\text { your nose up } \\
\underline{\text { at people }}\end{array}$ & $\begin{array}{l}\text { And turn not } \\
\text { your face away } \\
\text { from men with } \\
\text { pride }\end{array}$ \\
\hline و اخفض لهما جناح & Al-Isra, 17:24 & $\begin{array}{l}\text { And, out of } \\
\text { kindness, lower } \\
\text { to them the wing } \\
\text { of humility }\end{array}$ & $\begin{array}{l}\text { and lower to } \\
\text { them the wing of } \\
\text { humbleness out } \\
\text { of mercy }\end{array}$ & $\begin{array}{l}\text { and spread over } \\
\text { them humbly } \\
\text { the wings of thy } \\
\underline{\text { tenderness }}\end{array}$ & $\begin{array}{l}\text { and lower } \\
\text { your wing } \\
\text { in humility } \\
\text { towards them } \\
\text { in kindness }\end{array}$ & $\begin{array}{l}\text { And lower unto } \\
\text { them the wing } \\
\text { of submission } \\
\text { and humility } \\
\text { through mercy }\end{array}$ \\
\hline 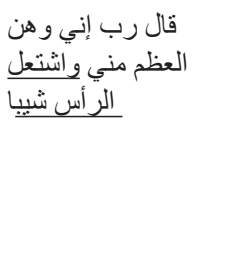 & Maryam, 19:4 & $\begin{array}{l}\text { Praying: "O my } \\
\text { Lord! infirm } \\
\text { indeed are my } \\
\text { bones, and the } \\
\text { hair of my head } \\
\text { doth glisten with } \\
\text { grey }\end{array}$ & $\begin{array}{l}\text { saying, 'O my } \\
\text { Lord, behold } \\
\text { the bones within } \\
\text { me are feeble } \\
\text { and my head is } \\
\text { all aflame with } \\
\text { hoariness }\end{array}$ & $\begin{array}{l}\text { he prayed: “O } \\
\text { my Sustainer! } \\
\text { Feeble have } \\
\text { become my } \\
\text { bones, and my } \\
\text { head glistens } \\
\text { with grey hair }\end{array}$ & $\begin{array}{l}\text { Lord, my } \\
\text { bones have } \\
\text { weakened and } \\
\text { my hair is } \\
\text { ashen grey }\end{array}$ & $\begin{array}{l}\text { Saying: "My } \\
\text { Lord! Indeed } \\
\text { my bones have } \\
\text { grown feeble, } \\
\text { and grey hair } \\
\text { has spread on } \\
\text { my head }\end{array}$ \\
\hline 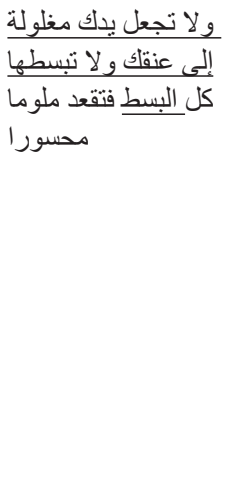 & Al-Isra, 17:49 & $\begin{array}{l}\text { Make not thy } \\
\text { hand tied (like a } \\
\text { niggard's) to thy } \\
\text { neck, nor stretch } \\
\text { it forth to its } \\
\text { utmost reach, so } \\
\text { that thou become } \\
\text { blameworthy and } \\
\text { destitute }\end{array}$ & $\begin{array}{l}\text { And keep not } \\
\text { thy hand chained } \\
\text { to thy neck, } \\
\text { nor outspread } \\
\text { it widespread } \\
\text { altogether, or } \\
\text { thou wilt sit } \\
\text { reproached and } \\
\text { denuded }\end{array}$ & $\begin{array}{l}\text { And neither } \\
\text { allow thy hand } \\
\text { to remain } \\
\text { shackled to } \\
\text { thy neck, nor } \\
\text { stretch it forth } \\
\text { to the utmost } \\
\text { limit [of thy } \\
\text { capacity], lest } \\
\text { thou find thyself } \\
\text { blamed [by thy } \\
\text { dependents], or } \\
\text { even destitute }\end{array}$ & $\begin{array}{l}\frac{\text { Do not be }}{\text { tight-fisted, }} \\
\text { nor so open- } \\
\text { handed that } \\
\text { you end up } \\
\text { blamed and } \\
\text { overwhelmed } \\
\text { with regret }\end{array}$ & $\begin{array}{l}\text { And let not your } \\
\text { hand be tied } \\
\text { (like a miser) to } \\
\text { your neck, nor } \\
\text { stretch it forth } \\
\text { to its utmost } \\
\text { reach (like a } \\
\text { spendthrift), so } \\
\text { that you become } \\
\text { blameworthy } \\
\text { and in severe } \\
\text { poverty }\end{array}$ \\
\hline
\end{tabular}

\begin{tabular}{|c|c|c|c|c|c|c|}
\hline 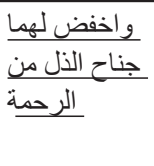 & Al-Isra, 17:24 & $\begin{array}{l}\text { And, out of } \\
\text { kindness, lower to } \\
\text { them the wing of } \\
\underline{\text { humility }}\end{array}$ & $\begin{array}{l}\text { and lower to } \\
\text { them the wing } \\
\text { of humbleness } \\
\text { out of mercy }\end{array}$ & $\begin{array}{l}\text { and spread over } \\
\text { them humbly } \\
\text { the wings of } \\
\text { thy tenderness }\end{array}$ & $\begin{array}{l}\text { and lower your } \\
\text { wing in humility } \\
\text { towards them in } \\
\text { kindness }\end{array}$ & $\begin{array}{l}\text { And lower unto them } \\
\text { the wing of submission } \\
\text { and humility through } \\
\underline{\text { mercy }}\end{array}$ \\
\hline
\end{tabular}


direct translation often leads to distortion and ambiguity. The intended meaning of the above is simply my hair has turned grey. Translating is not a form of duplication, particularly when dealing with sensitive texts like the Quran, but a means of conveying meaning. The translator's main task is not so much about recovery but the discovery of meaning. The best approach when dealing with Quranic phraseology in translation is to consider the degree of translatability i.e. whether the equivalent expressions enjoy the same stylistic value in their respective contexts and cultures.

ولا تجعل يدك مغلولة إلى عنقك ولا تبسطها كل As regards the verse البسط فتقعد ملوما محسورا. if translation is the art of negotiation and compromise, Ali's effort is far from achieving this purpose, using terms which are not in common use in the modern era: Make not thy hand tied (like a niggard's) to thy neck, nor stretch it forth to its utmost reach, so that thou become blameworthy and destitute.

The above phraseological unit carries a straightforward meaning not different from its surface meaning. This literal translation, without regard to the connotative or contextual meaning can be erroneous. Often translating the form, not the content or substance of what the Quran actually says and means, has led to controversy. The basic message intended is do not be tight-fisted nor lavish. In other words the message could be simplified as And let not your hand be chained to your neck nor open it completely lest you regret it.

The density and the way Quranic phraseology is formulated and articulated is unique and it is a tall order to produce a matching phraseology in English, as evidence shows from the above small sample. The way meaning is distributed, and the way phraseological components are emphasised in the Quran should be rendered in meaning only, not in form.

To conclude, most translations have their limitations and the translations of the Quran are no exception. A further challenge is that the Quranic text transcends to some- thing which may, in reality, be inexpressible in translation. The five translations of the Quran are undoubtedly useful but there is plenty of room for improvement for each one of them. Vagueness, distorted meaning and incoherence in parts seem to be evident in many of the translations of the Quran.

\section{ANTONYMY IN THE QURAN}

In addition to phraseological units, collocations and other word combinations, the Quran makes extensive use of antonymy. Antonymy is described as the close semantic relationship that lexical items with opposite meaning form. Antonymy is viewed by many authors as one of the most important semantic relations between words and/or word-senses (Murphy 2003, Jones et al. 2012, Cruse, 1986). Antonyms can be defined as lexical pairs which express opposite or incompatible meanings, e.g. In sickness and in health, for better or for worse, war and peace.

Antonyms or pairs of words are often used in the Quran to achieve rhetorical effects. For instance, the term sky

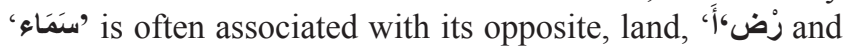

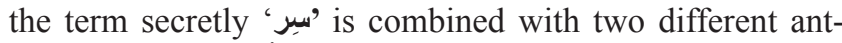

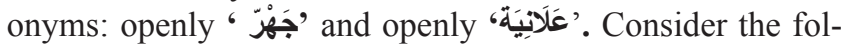
lowing sample of Quranic antonyms:

As the above table shows, there is a plethora of Quran antonyms. This concurrent use of lexical combinations with opposite meaning can be challenging to grasp and render efficiently in English, as highlighted in the above five translations. This view is supported by Al-Kharabsheh and Al-Jdayeh (2017:1) who point out that: 'Quranic antonymy represents a case of semantic non-identicality, where two distinct levels of inverse semantic duplicity exist simultaneously: an overt one at the basic level, and a covert one at the metaphorical level.' The above translations of Quranic autonyms are inevitably just approximations. The incompat-

\begin{tabular}{|c|c|c|c|c|c|c|}
\hline مني هن الشتعل & Maryam, 19:4 & $\begin{array}{l}\text { Praying: "O my } \\
\text { Lord! infirm } \\
\text { indeed are my } \\
\text { bones, and the } \\
\text { hair of my head } \\
\text { doth glisten with } \\
\text { grey }\end{array}$ & $\begin{array}{l}\text { saying, 'O my } \\
\text { Lord, behold } \\
\text { the bones } \\
\text { within me are } \\
\text { feeble and } \\
\text { my head is all } \\
\text { aflame with } \\
\text { hoariness }\end{array}$ & $\begin{array}{l}\text { he prayed: "O } \\
\text { my Sustainer! } \\
\text { Feeble have } \\
\text { become my } \\
\text { bones, and my } \\
\text { head glistens } \\
\text { with grey hair }\end{array}$ & $\begin{array}{l}\text { Lord, my } \\
\text { bones have } \\
\text { weakened, } \\
\text { and my hair } \\
\text { is ashen grey }\end{array}$ & $\begin{array}{l}\text { Saying: "My Lord! } \\
\text { Indeed my bones } \\
\text { have grown feeble, } \\
\text { and grey hair has } \\
\text { spread on my head }\end{array}$ \\
\hline
\end{tabular}

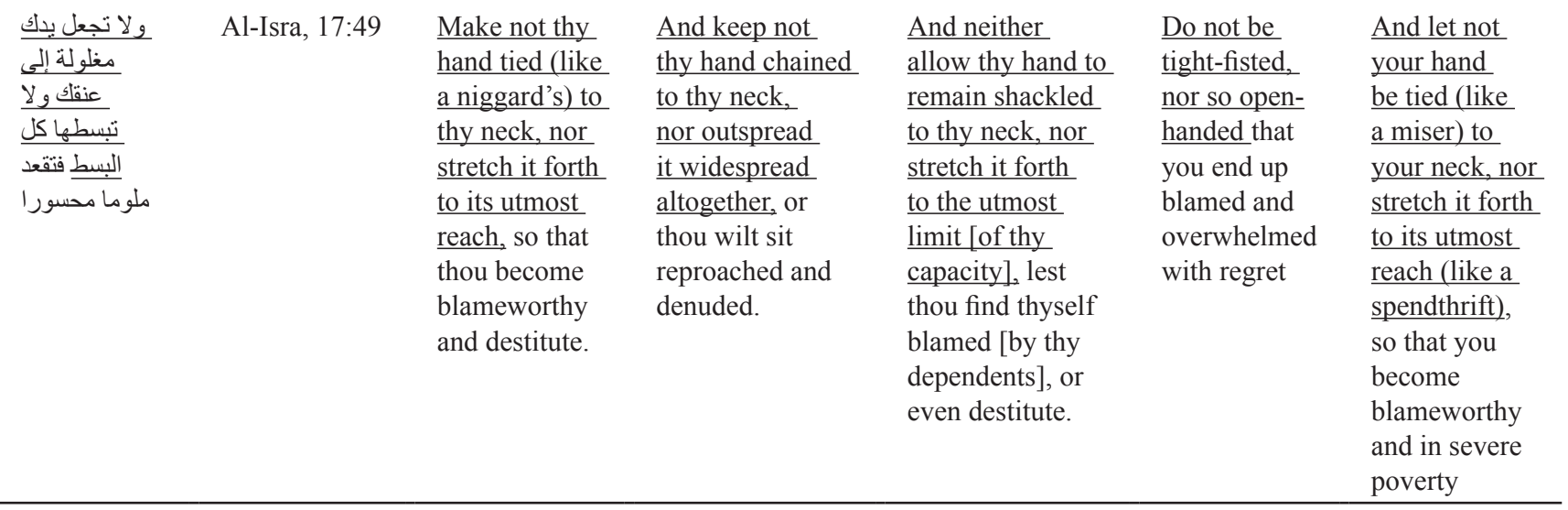




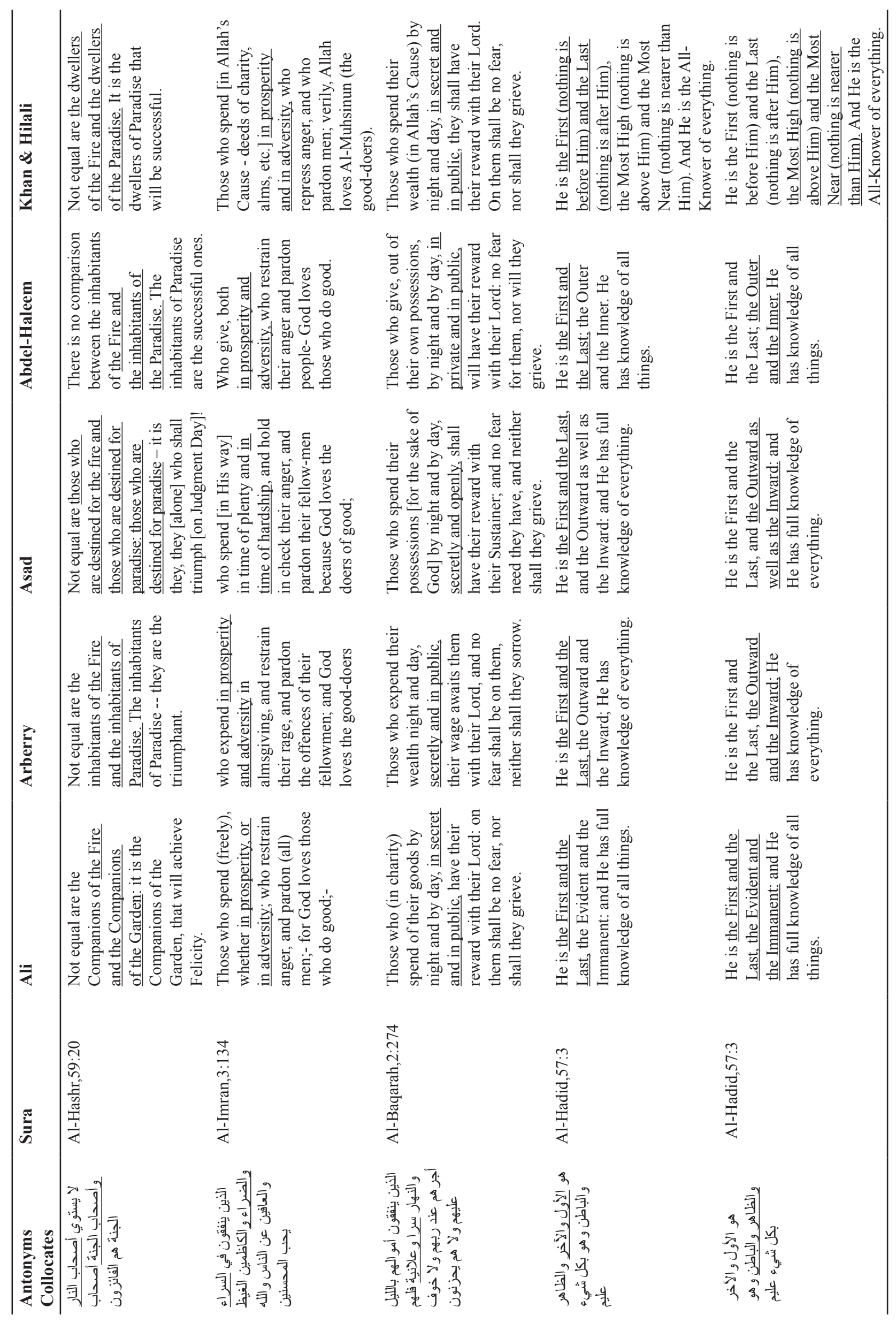




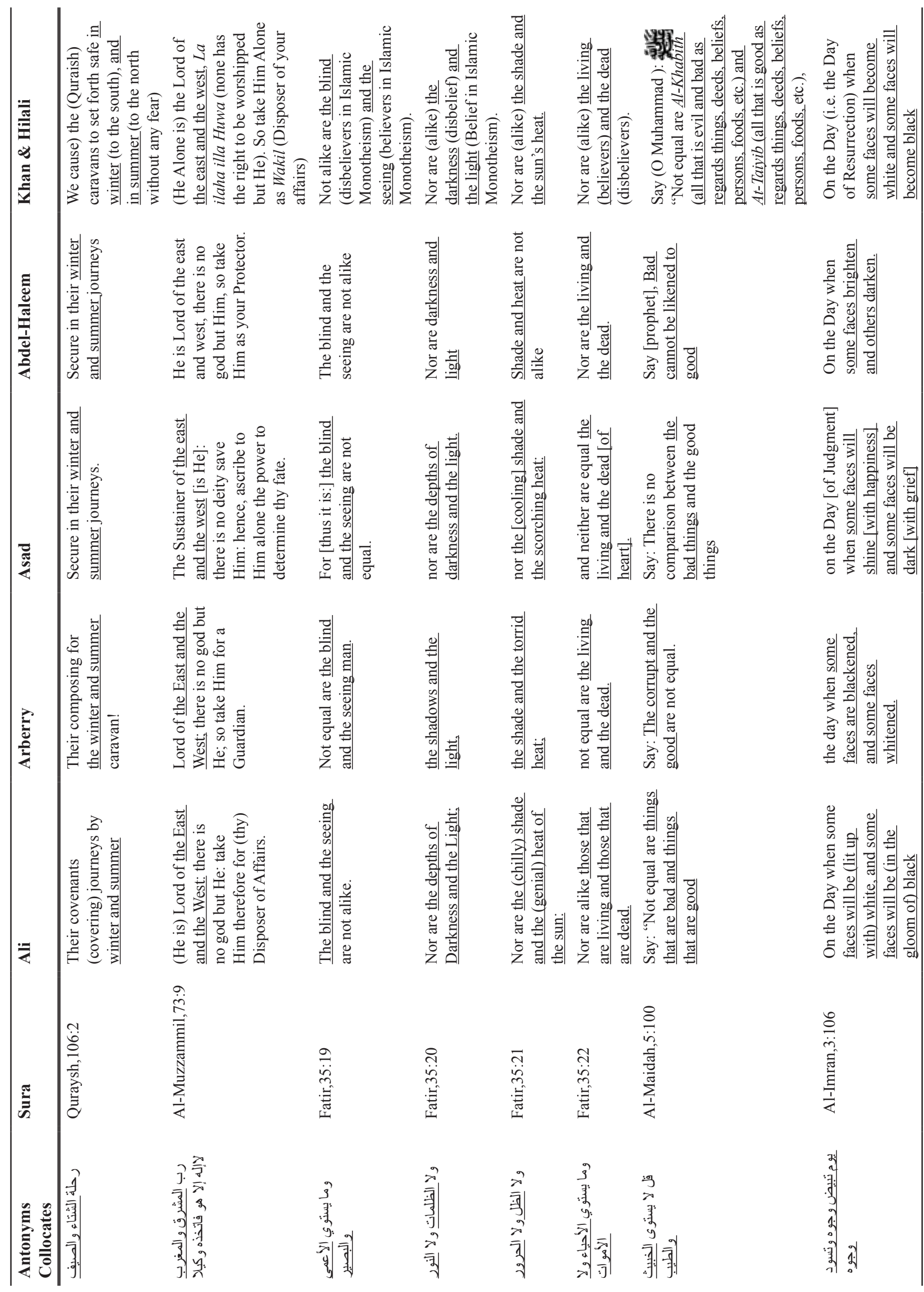




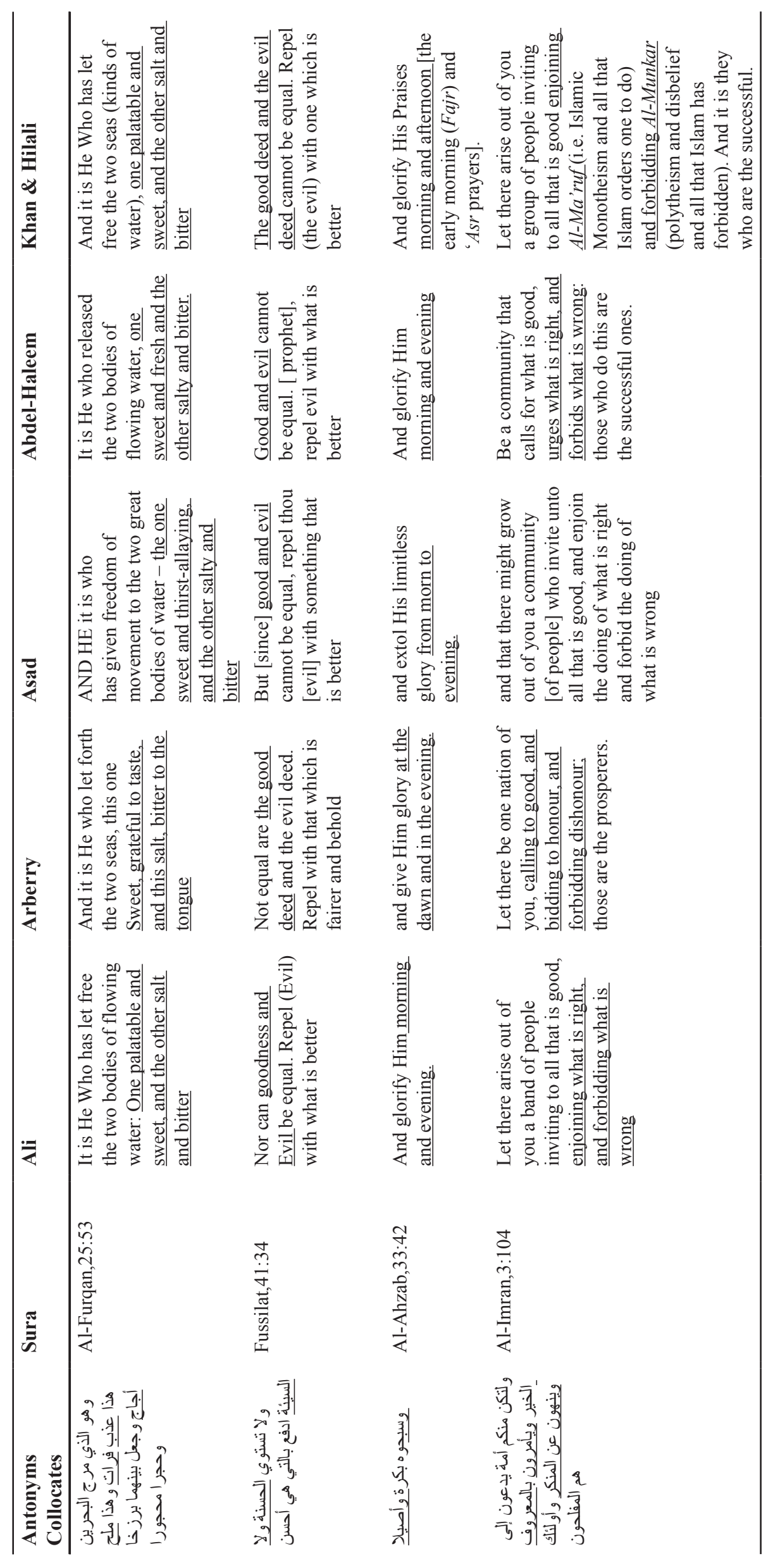


ible information contained in these autonym pairs is more extensive than a translation can convey.

\section{CONCLUDING REMARKS}

Research on phraseology as a recurring word combination has a broad scope with the dual purposes of contributing to the theoretical knowledge base on collocation and to make collocation learnable and teachable to second language learners. Research on collocations is polarised between those who examined them from a statistical perspective, as frequency-based lexical units, while others viewed them from a conventional perspective as usage-based lexically restricted units (Granger and Paquot, 2008). Although collocation in its generic sense is understood to mean a close relationship that words form and then frequently appear together, it is often used as an umbrella term to refer to a wide variety of labels such as: 'phraseological units, language chunks, extended lexical units, fixed expressions, formulaic sequences, predictable pattern, etc.' Many definitions of phraseological units tend to overlap. Wray (2000: 465) highlighted some 50 terms that have been used to refer to phraseological units. Many studies on collocations and phraseological units are written in a language that is either ambiguous or highly jargonistic. There is a need to demystify and standardise the research and move it beyond what is already known and established as the base.

The assessed sample of Quranic collocations across five translations have their strengths, but also their weaknesses. The English translations of the Quran, and its formulaic expressions in particular, tend to be influenced by 'word-forword' translation. In the main, the translators were not exploratory enough and stayed close to the source language, rendering the word rather than the meaning, instead of translating the message and providing the gist of what was said in Arabic, seeking to preserve the sense as much as possible. A 'thought for thought' translation would be the best choice to accurately convey what the original phraseological units say. Some translators have underestimated the complexity of translating Quranic formulaic expressions. The above small sample shows that transferring just the words in English leaves behind the meaning, the rhythmic and poetic effect of the Quran. One of the major challenges of translating the Quran is that each word has rarely a precise equivalent in English. Thus, to transfer Quranic phraseological units literally, is not a sufficient guarantee of making the text accessible and understandable in the target language. Between word-for-word or sense-for-sense translation approaches, the translator of the Quran walks a tightrope; he/she must have a grasp of the centre of gravity, a sense of balance. The language of the Quran is used in an individual and creative way in order to convey a particular meaning and strike a chord to elicit and trigger a strong emotional response. Thus, any future translation of the Quran should be a collective effort, not an individual endeavour. The translator should translate the embedded message of the phraseology, not the form of the word combination, the matter not the manner. To translate the meaning not the word should be the main aim of the translator.

\section{REFERENCES}

Abdel Haleem, M. (2004). The Qur'an. New York: Oxford University Press.

Ali, A. (2015). The Holy Qur'ān. New Delhi: Kitab Bhavan.

Al-Kharabsheh, A. and Al-Jdayeh, G. (2017). Translatability of Quranic Antonymy. Jordan Journal of Modern Languages and Literature, 9 (1), pp. 51-72.

Arberry, A. (2008). The Holy Koran. London: Routledge.

Asad, M. (1980). The message of the Quran. Gibraltar: Dar Al-Andalus Ltd.

Bani-Younis, M. (2015). Cultural and Sociolinguistic Issues in English-Arabic translation of Collocations. Studies in Literature and Language, 10 (6), pp.53-58.

Baker, M. (1992). In Other Words: A Course Book on Translation. London: Routledge.

Bannister, A. (2017). Oral-Formulaic Study of The Quran. [S.1.]: Lexington Books.

Cowie, A. P. (1981). The Treatment of Collocations and Idioms in Learner Dictionaries. Applied Linguistics. 2, 223-235. http://dx.doi.org/10.1093/applin/2.3.223.

Cowie, A. P. (1991). Multiword units in newspaper language. In S. Granger (Ed.), Perspectives on the English lexicon: A tribute to Jacques Van Roey (pp. 101-116). Louvain-la-Neuve: Cahiers de I 'Institut de Linguistique de Louvain.

Cowie, A. P. (1994). "Phraseology". In: R. Asher (ed), The Encyclopaedia of language and linguistics. Oxford: Oxford University Press. 3168-3171.

Cowie, A. P. (2009). Semantics. Oxford: Oxford University Press.

Cruse, D. A. (1986) Lexical Semantics. Cambridge: Cambridge University Press.

Cumming, S. (1986). The Lexicon in Text Generation. Paper presented at the LSA Linguistics Institute Workshop on Lexicon. New York.

Delisle, J. And Woodsworth, J. (1995) Translators through History. John Benjamins Publishing Company. UNESCO Publishing.

Dweik, B\& Abu Shakra, M. (2011). Problems in translating collocations in religious texts from Arabic into English. The Linguistics Journal. Middle Jordan.5(1).

Gledhill, C. (2011). The 'lexicogrammar' approach to analysing phraseology and collocation in ESP texts. 5-23.

Granger, S. and Meunier, F. (2008). Phraseology: An interdisciplinary perspective. Philadelphia, PA: John Benjamins Publishing Company.

Granger, S., and Paquot, M. (2008). Disentangling the phraseological web. In S. Granger, and F. Meunier (Eds.), Phraseology: Interdisciplinary perspective, pp., 27-49. Amsterdam: Benjamins.

Herbst, T. (1996). What are Collocations: Sandy beaches or False Teeth? English Studies. Vol 77(4),379-393.

Hilali, T. and Khan, M. (1983). Translation of the meanings of the Noble Quran in the English Language. Riyadh: Dar-Us-Salam.

Howarth, P. (1996). Phraseology in English academic writing: Some implications for language learning and dictionary making. T übingen: Niemeyer. 
Howarth, P. (1998). The phraseology of learners' academic writing. In A. P. Cowie (Ed.), Phraseology: Theory, analysis and applications. Oxford: Oxford University Press. pp. 161-186.

Jabak, O.O. Abdullah, S.N.S, Mustapha, N.F. (2016).The Difficulty of Translating Collocations from Arabic into English Encountered by a Sample of Arab Students VOL 3 BIL 1 (JUN 2016) journal.kuis.edu.my/jsass/images/ files4b/4_025-Omar.pdf e-ISSN: 22898042

Jones, S. Murphy, C. P. \& Caroline W. (2012). Antonyms in English: Construals, constructions and canonicity. Cambridge University Press, Cambridge, UK.

Khaleel, M. (2005). Assessing English Translations of the Quran. San Diego State University: San Diego.

Kjellmer, G. (1987). Aspects of English collocations. In W. Meijs (Ed.), Corpus Linguistics and Beyond: Proceedings of the Seventh International Conference on English Language Research on Computerized Corpora. 133-140.

Kjellmer, G. (1991). A mint of phrases. In K. Aijmer \& B. Altenberg (Eds.), English corpus linguistics. Studies in honour of Jan Svartvik. London: Longman. 111-127.

Kjellmer, G. (1994). A dictionary of English collocations: Based on the Brown corpus. Oxford: Clarendon Press.

Meer, G. Van der (1998). Collocations as One Particular Type of Conventional Word Combination: their definition and Character, in Fontenelle et al. 313-323.

Mel'Čuk, I. (2012). Phraseology in the language, in the dictionary, and in the computer. Yearbook of Phraseology, 3(1), pp. 31-56.

Meunier, F. and Granger, S. (2008). Phraseology in foreign language learning and teaching. Philadelphia, PA: John Benjamins Publishing Company.

Moon, R.1997. 'Vocabulary connections: multiword items in English' in N. Schmitt and M. McCarthy (eds.). Vocabulary: Description, Acquisition and Pedagogy. Cambridge: Cambridge University Press.

Moon, R. (1998). Fixed Expressions and Idioms in English: A corpus-based approach. Oxford, Oxford University Press.
Moon. R. (2008). Dictionaries and collocations. In F. Meunier and S. Granger (eds.). Phraseology in Foreign Language Learning and Teaching. Amsterdam: John Benjamins. 247-252.

Murphy, M. L. (2003). Semantic relations and the lexicon: antonymy, synonymy, and other paradigms: Cambridge. Cambridge University Press.

Naciscione, A., (2001). Phraseological Units in Discourse: Towards Applied Stylistics. Riga: Latvian Academy of Culture.

Nattinger, J., \& DeCarrico, J. (1992). Lexical phrases and language teaching. Oxford: Oxford University Press.

Nerlich, B. and Clarke, D. (2001). Serial metonymy: A study of reference-based polysemisation. Journal of Historical Pragmatics, 2(2), pp.245-272.

Nikulina, E. (2015). English Phraseology: Integration with Terminology Science. Journal of Language and Education, 1(2), pp.41-45.

Pickthall, M.M. (1935). The Meaning of the Glorious Quran with Brief Explanatory Notes and Brief Subject Index. Amana Publications (31 Aug. 1996)

Römer, U. and Schulze, R. (eds) 2009. Exploring the lexis-grammar interface. Amsterdam: John Benjamins Publishing Company.

Sinclair, J. (1966). Beginning the study of lexis. In C. Bazell, J. Catford, M. Halliday\& R. Robins (eds). 410-430. London: Longman.

Sinclair, J. (1991). Corpus, Concordance, Collocation. Oxford: Oxford University Press.

Sinclair, J. (2004). Trust the text. London: Routledge.

Steyer, K. (2015). Patterns. Phraseology in a state of flux International Journal of Lexicography, Volume 28, Issue 3, 1 September 2015, Pages 279-298, https://doi. org/10.1093/ij1/ecv021

Stubbs, M. (2001). Words and phrases. Corpus studies of lexical semantics. Oxford, Blackwell.

Wray, A. (2000). 'Formulaic Sequences in Second Language Teaching: Principle and Practice'. Applied Linguistics. 21(4), 463-489. 